\title{
アイヌのトリカブト矢毒について*
}

その微量化學的研究

石川元助

I. はしがき

北海道アイメがかつて使用した主な矢毒（アイヌ語：ayoop）はブン(附子)、すなわち トリカブト (Aconite) の根部 (Fig. 1，2）から調製されたものであると言われている。

しかし、矢毒そのものの化學的成分の研究、特に民族植物學的觀點からする賽證的研究が 未だなされたことを聞かない。古野 $(1942,1948)$ 、三上 (1943) 等の著書、論交にしても化 學的成分には觸れていない。わずか炕關場 (1896) が北海道重卜リカブト根から抽出した粗 Alkaloids で動物賽驗をなしているに過ぎない。他にも矢毒に關する報告が二、三あるが Original なものではない。

著者は日頃、民族學に於ける一方法論として、實驗科學的研究法を提唱してきた。人類社 會に發生した、或は發生する文化現象の把握乃至理解の方法に於て、所謂人文科學的視點の 場合は、とかく、Data の抽出、Integration 及びその Reconstruction 等飞於て科學性

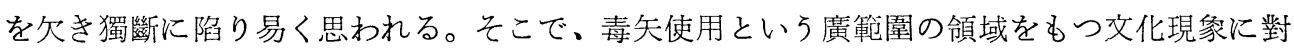
しては、交献學的（從來の意味に於ける）研究の夕では不充分と思考されるので、比較すべ きData の科學的集得が必要である。口碑、傳說、古交献等も、それぞれ意義を有し、重

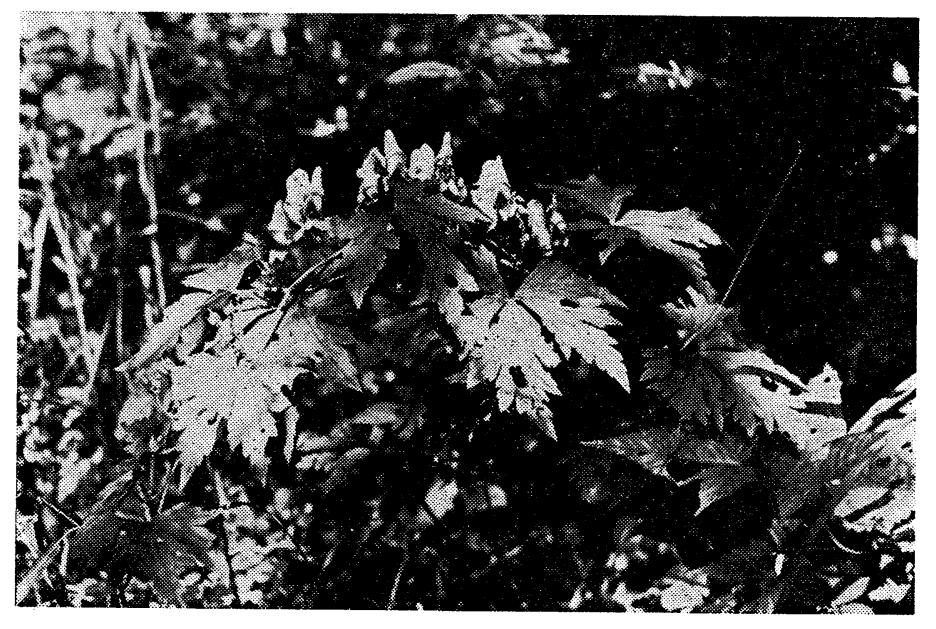

Fig. 1. Flowering Aconitum sp. in Mt. Takamaru near Mt. Kumotori, central Honshu. (Sept. 17, 1950;
要な資料ではあるが。 現存する歷史的、乃至 は文化荷擔者である直 接的な遺跡、遺物、標 本等はなお一層の價值 をもつものであること は論を俟たない。

毒矢使用といら文化 現象も、遺物或は標本 等を檢體として、"如 何なる構造と機能を有 するか、塗毒された物 質は、自然物なりや。 合成物なりや“等の

* 交部省科學研究助成補助金による研労の一部、昭和 29 年度、課題番號 20081 
疑問を解決するため、化學的藥理學的等一連 の自然科學的操作が必要である。かつる意味 に於て、近時目覺しい發達を遂げた微量化學 (Micro-chemistry) の方法を民族學に導入 し、アイヌの矢毒を實證的に研究したのでこ こ報告する。

L. LEWIN (1923) は上部 Assam 地方の トリカブト系矢毒について分析を賽施した が、試料が微量なため、その成分を確定し得 なかつたと報告し、又 J. H. Hurron (1938) は Assam の Naga 族の毒矢を Calcuṭta で實驗させたが、トリカブトであるかどうか は確定出來なかつた。それかと言つて、否定 する祆料もなかつたと述べている。

上例に於ても、當時の化學的水準からすれ

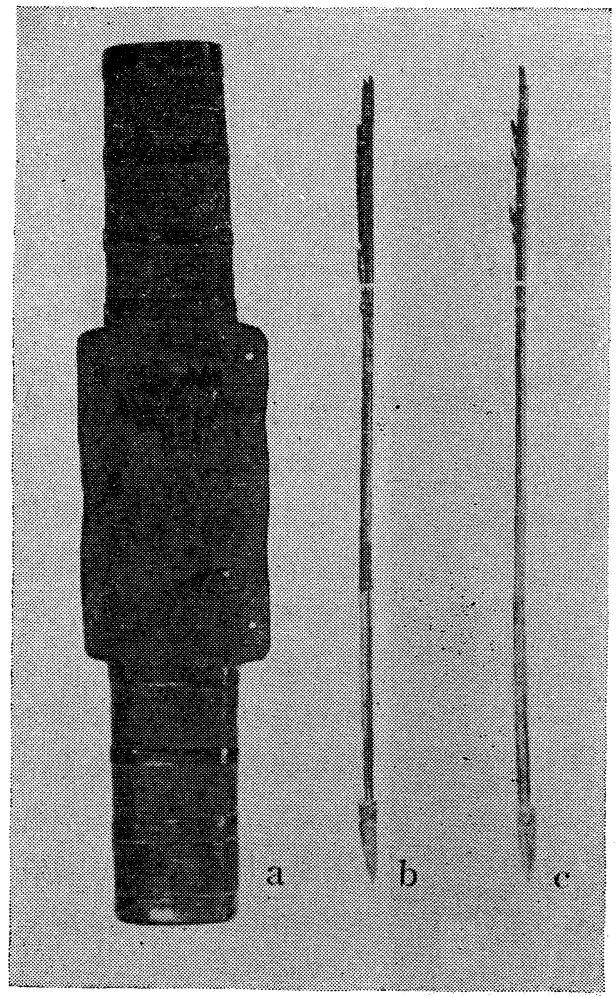

Fig. 3. Arrow case and arrows with poisoned head of Ainu. (a. F-407, b. F-263 c. F-259. $\cdots 1 / 6$ actual size (Anthr. Inst. Fac. Sci. Univ. Tokyo)

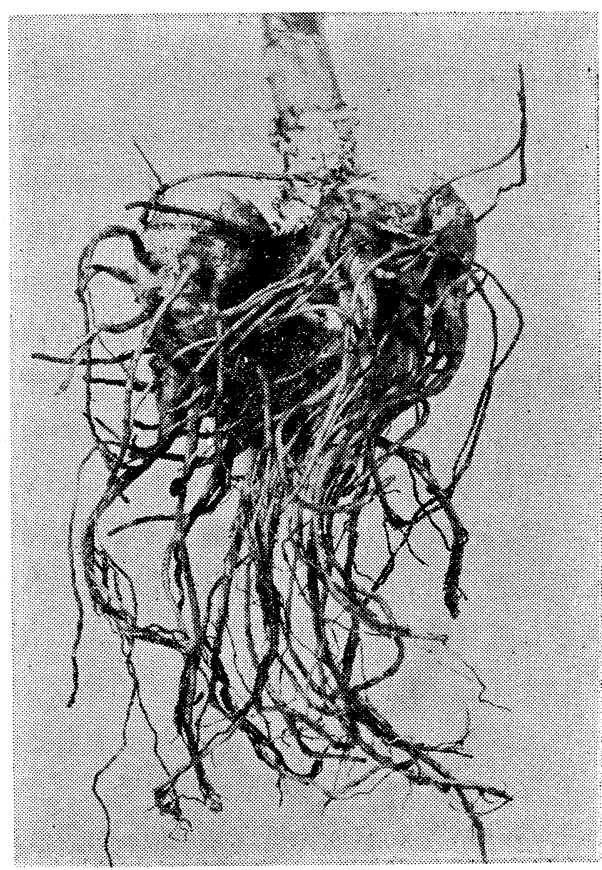

Fig. 2. Root of Aconitum sp. from Tokura, Gnnma Pref. (Sept. 7, 1952)

ば、相當高度な處理をなしたにもかつわらず含 有成分も確定し得ず、且つ Original Plants の同定もなし得なかつたのは、矢毒は種々なる 物質の混合物であつて、その複雜性の故に成分 の單離が困難であるからである。

しかしながら將來、良好な試料を得れば必ず 解決される問題である。

\section{II. 矢毒詿料の民族學的考察}

本實驗に使用した矢毒試料は東京大學理學部 人類學教室所藏になる採集地、採集年月日等は 不明であるが、北海道アイヌが使用したと思わ れる毒矢 11 本（標本番號 F-247, 250, 254, 258, $259,260,263,406$; 以上 8 本竹製やじり付、 F-264, 265, 266; 以上 3 本、鐵製やじり付) の 內 2 本 (F-263, 259-Fig. 3 b, c 參照) の竹製 やじり (アイヌ語 : rum, Fig. 4 a, b 參照) の凹部に固着していた黑褐色物質を削り取つた ものである。その採取量は F-259 から 3mg, (17) 
F-263 から $1.5 \mathrm{mg}$ であつた。參考のため毒矢の諸元を述べて扰く。全長、 $49.5 \sim 50 \mathrm{~cm}$ 、 重量 15 15.5 g、やじりは竹製長さ 47〜 55 mm、巾 $14 \mathrm{~mm}$, 植物性㵶維で緊縛し樹脂で 中間軸（アイヌ語：makanit）に膠著されている。中間軸は骨製、斷面は冒形 (F-259) 及 び形 (F-263) である。矢柄（アイヌ語：aysup）は笋シ（ヨシ）製で直徑 $8 \mathrm{~mm}$ 前後。 矢狗（アイ又語：ayrap）は2枚（4枚のものもある）で、やじりに對し十字形に縛着され ている。重心位置は、やじり先端から測つて $\frac{1}{3}$ 點にある。

以上の諸元から機能を考察すると、これは近距離々頭式毒矢である。やじり、矢柄、共に 輕量なため中間軸に骨を利用して重量を補足し、重心位置を前方にもたせた點、矢旸がやじ りに對して十字形に構成されている點から、これ等は矢の飛行に全く有效な技術的考案であ つて流體力學の原理に合致するものである。矢の飛行は直線的で 回轉しないのが特徴であ る。厼、Fig. $4 \mathrm{c}$ に示した骨製やじりは早稻田大學考古學研究室の㴰口㸚授、大川清氏等が 北海道禮文郡、船泊村上泊のオホック文化期貝塚から發掘したもので、塗毒し易いやじりの 例として參考のため揭出しておく。

次に Fig. 3 a に示す䇤筒（アイヌ語：pus-ni 標本番號 F-407) の外側にさくら樹皮帶 で上中下の三段に (Fig. 5) 、あたかも近代銃器の彈帶の如く、各段には多分 5 本宛の竹製 やじりが裝著してあつた思考されるが（中、下段は破損している）その現存する上段の 5 本 の rum から黑褐色物質 $260 \mathrm{mg}$.を刢り取つて試料とした。

この彈帶樣の Idea は離頭式やじりの交換性を決定づけるものであつて、すばらしい發
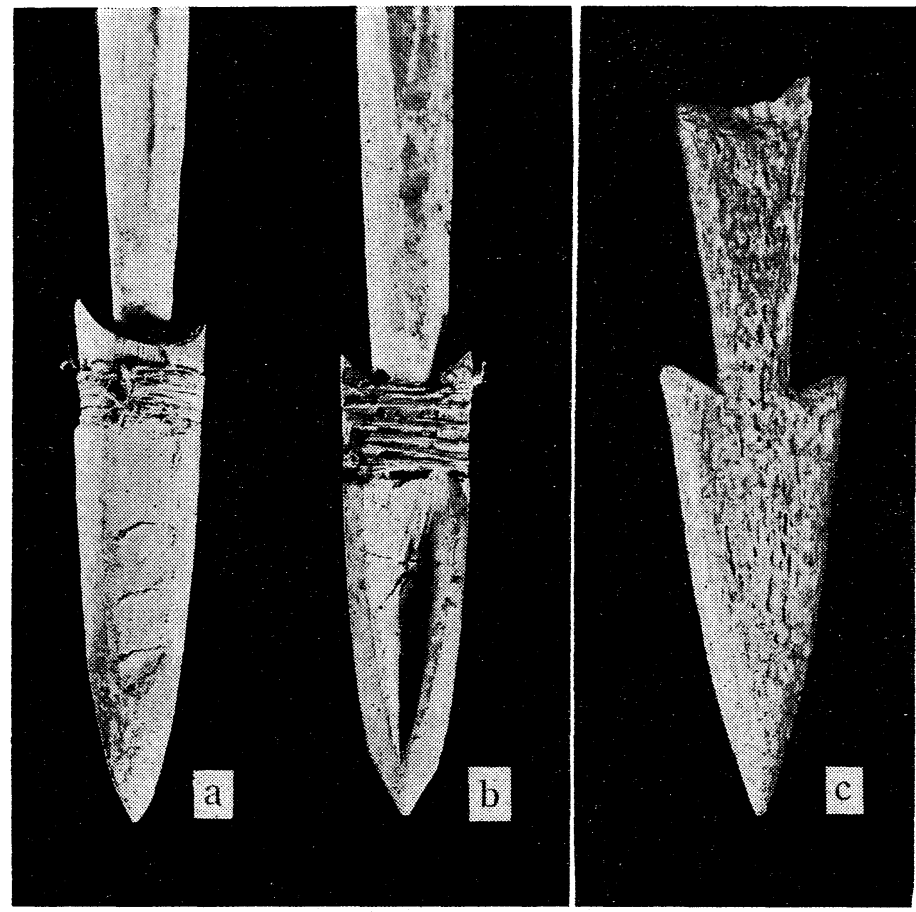

Fig. 4. Detail of poisoned bamboo arrow heads (a. F-263, b. F-259) and bone arrow head (c). (Actual size)
明と言わなければなら ない。矢筒の諸元は全 長、 $52.5 \mathrm{~cm}$ 、彈帶部の 巾 $11.5 \mathrm{~cm}$ 、厚さ $4 \mathrm{~cm}$ 。 斷面は長隋圓形である。 收納矢數は 10〜15 本位 と思われる。

ここに探集された黑褐 色物質は如何なる性質を もつ矢毒である5か、そ の手がかりとしてアイヌ の毒矢の習俗に關する文 献を調べる必要がある。 例へば、松浦武四郎の東 蝦夷日誌初篇に「烏頭根 に烟草の脂と知蛛クルン 八（長五六分水中石につ く虫也）と四種を練合し て筒に入腐らし用ゆる と、然し是を用ひて取り 
しは其肉に毒迴りて動もすれば喰し者に當る故今は烏頭一味にて製す。然れば毒の迴り遲け れ共、肉を捨てる所少しと話しぬ」と見えている。烏頭は附子の母根を指す名稱であつて、 トリカブト根である。その他の文献も大同少異である。次に知里 (1953) によつて、アイ又 の矢毒に混合される物質を考察しよ5。

トリカブトAconitum spp. の項目 (249) は p. 139 から p.148 まで 8 頁に涉り詳述され ている。まずトリカブトのアイヌ名は北海道では SURKU (súr-ku)、樺太では SURUKU (surú-ku) であり。又北海道アイヌは毒性の强弱によつて 5 6 種に分類している。（しか しながら、アイヌ名とトリカブト屬植物の和名、學名との對比がなされていないのが殘念で ある。宮部 (1943) の「アイ又植物名に就いて」でも余りはつきりしていない。關場 (1896) も宮部博士に依り 6 種の雙荋菊一トリカブトの別名一ありと報告しているがこの分類もおか しい。) 矢毒 (ayyop) には中心㐫方市の (ikkew) として surku を使う他に次のような

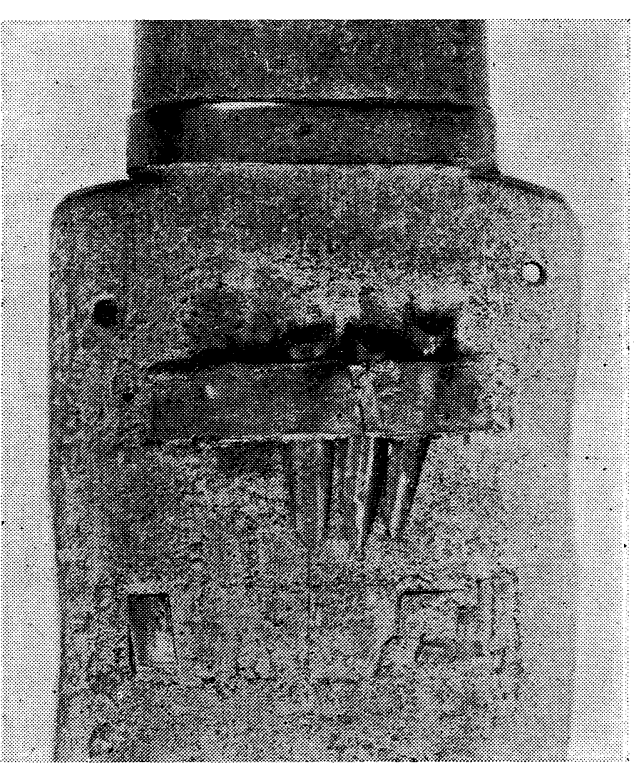

Fig. 5. Detail of an arrow case with poisoned bamboo arrow heads. (1/2 actual size) ものも使う。(1)トリカブトの根ばかりで なく、新芽、葉。(2) エゾテンナンンヨウの 根、種子。(3) 煙草或はそのヤ二。(4) 唐辛 子。(5) ベニバナヒヨウタンボクの枝。(6) ハナヒリノキの搔き履。(7) ヨモギの葉。 (8) エンレイソウの果賽。(9) イチゴの喿 貫。(10) 松ヤ二 (11) 毒ぐも。(12) worumpe と稱するマツモムン科の毒虫。(13) pekakarpe と稱するミズスマン科の虫。(14) フ グの油。(15) 狐の膽汁。(16) 鹿の油。(17) 唾 液等 17 種類である。

これ等が全て混合されているわけではな く、トリカブト根を中心として、大體數種類 が混合されていると推定される。この中で 矢毒成分の檢討に問題になるのは (1) (2) (3) (6) である。(1) のトリ劣ブトは矢毒の ikkew となるもので著者は基本毒 (Basic poison) と呼び、(2) (3) (6) 等は補助毒 (Adjuvant poison) と名づけている。 (2) エゾテンナンンョウ Arisaema peninsulae Nakai は成分不詳であるが有毒である。タバコ Nicotiana tabacum L. は有毒 Alkaloid Nicotine $\left(\mathrm{C}_{10} \mathrm{H}_{14} \mathrm{~N}_{2}\right)$ を含有している。(3) ハナヒリノキ Leucothoe Grayana Maxim. には Grayanotoxin $\left(\mathrm{C}_{23} \mathrm{H}_{40} \mathrm{O}_{7}\right)$ なる有毒成分を含有する。この葉の粉末は微量でもクサ メを出さしたり、涙を流さしたりする。皮虑に作用すればかゆみや炎症を起す特性がある。 （東北地方ではクサメをハナヒリという）

以上の文献から黑褐色物質はトリカブトを主體とする複合毒であるということに略間違い ないと思われるが、Nicotine が混合された場合には成分の檢出が仲々困難になる。 
III. 北海道產トリカブト屬植物

中井 (1917) 飞依れば北海道產トリカブト屬植物 (Genus Aconitum) は次の通りであ る。

(1) Aconitum yesoense Nakai (1908) (14) エゾトリカブト

(2) A. subcunertum Nakai (1914) オクトリカブト

(3) A. yuparense Takeda (1915) ユウバリトリカブト

(4) A. corymififerum Nakai (1917) ウスバトリカブト

(5) A. lusiảuscu!um Nakai (1917) テリハブン

(1)、(3)、(4)、(5) は北海道原產であり (2) は奧咃方から北海道南部にかけて多く植生してい る。(分布は Fig. 6 參照)

もしアイヌが矢毒として上記植物の根部を使用したとすれば、どの Sepecies であろう か、そのためにはまず各植物の根部に含有される有毒成分を知らなければならない。すべて のトリカブト屬植物が有毒ではなく、中には矢毒として使用し得ないものがあるからである。 日本產トリカブトの有毒成分は歐洲產 トリカブトと同樣、Aconitine $\left(\mathrm{C}_{34} \mathrm{H}_{42}\right.$ $\left.\mathrm{O}_{11} \mathrm{~N}\right)$ を含み、その他に Mesacontine $\left(\mathrm{C}_{33} \mathrm{H}_{45} \mathrm{O}_{11} \mathrm{~N}\right)$, Hypaconitine $\left(\mathrm{C}_{33} \mathrm{H}_{45}\right.$ $\left.\mathrm{O}_{10} \mathrm{~N}\right)$ 及び Jesaconitine $\left(\mathrm{C}_{35} \mathrm{H}_{40} \mathrm{O}_{12} \mathrm{~N}\right)$ の 4 種等が主なものである。これを構造 上から見れば前三者は安息香酸及び䣷酸 のエステルであり、Jesaconitine はア 二ス酸及び酢酸のエステルである。しか もこれらは猛毒性の Alkaloids であつ て、充分矢毒に使用し得るものである。 その他にも低毒性乃至無毒の Alkaloids がある。現在まで低毒性及び猛毒性 $\mathrm{Al}$ kaloid を合わせれば約 40 種の Alkaloid が純粹分離されている。 HENRY (1949)はトリカブト屬植物の Alkaloids を大きく 2 群に分けている。第 1 類、 Aconitine 系一猛毒性を有するもの。 第 2 類、Atisine 系一低毒性のものとし ている。前記 5 種類の內、ウスバトリカ ブト、及びユウバリトリカブトの含有成

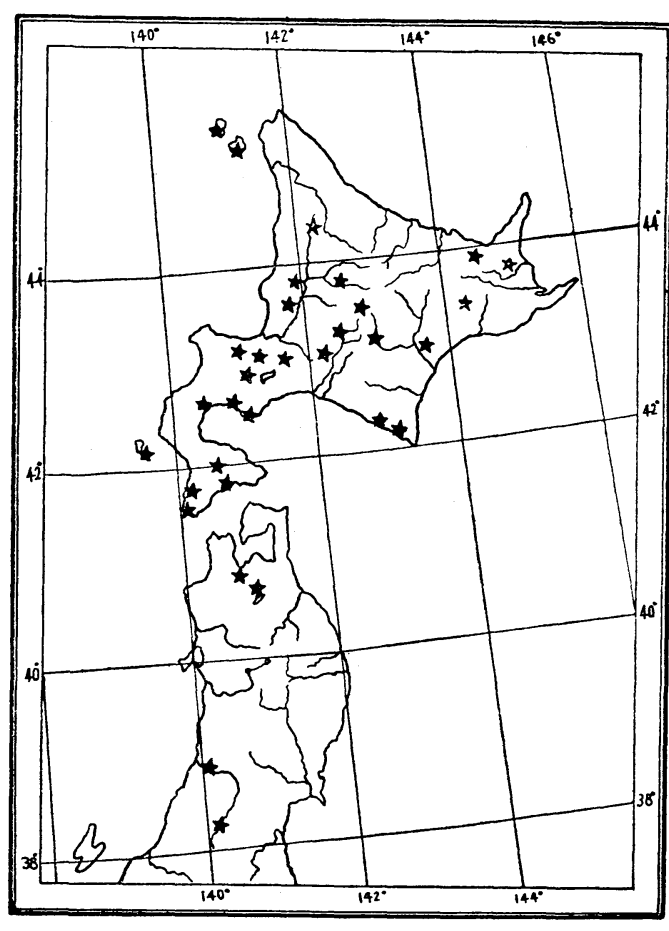

Fig. 6. Map showing occurence of Aconitum spp. from Hokkaido (Yeso) and northern part of Honshu. 分についての報告には未だ接していない。それ故有毒か無毒か制定し得ない。エゾトリカブ 卜は後述する如く有毒と考えられる。オクトリカブトは分布の廣い植生を有する種である が、杉野目 (1943)によれば、錢函産も秋田産も共に Aconitine 及び Jesaconitine を含 
有しているので猛毒であつて、HENRY 分類の第 1 類 Aconitine 系に屬するから矢毒とし

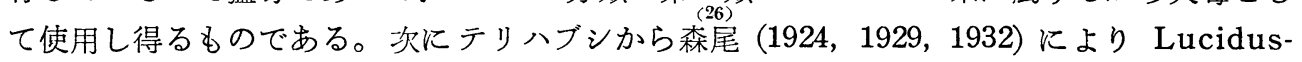
culine $\left(\mathrm{C}_{24} \mathrm{H}_{35} \mathrm{O}_{4} \mathrm{~N}\right)$ が抽出されたが、これは HENRY の第 2 類 Atisin 系 $\left(\mathrm{C}_{22} \mathrm{H}_{31} \mathrm{O}_{2} \mathrm{~N}\right)$ に近似するもので無毒のAlkaloid である。それ故矢毒には使用され得ないであろう。

それでは Aconitine 系の Alkaloids はどのような毒性を持つものであろうか、黑田 (1951) により各種動物に對する致死量 (Table. 1.) を揭出して檢討してみよう。表によれば 明かに Jesaconitine が最强毒であり、ついで Mesaconitine, Aconitine の順である。 今井 (1949) はトリカブト Alkaloids の毒性には種族差がある外、各動物について個性差 を認めている。溶液は調製後 3 日以內は殆ど作用度に變化を呈しないが、其の後は時日の經 過と共に輕度に減少すると述べている。

Table. 1. Lethal dosage for animals (LD.50)

(after A. KURODA, 1551) $\mathrm{mg} / \mathrm{kg}$.

\begin{tabular}{|c|c|c|c|c|}
\hline Animals & $\begin{array}{r}\text { Poisons } \\
\text { Administration } \\
\end{array}$ & Aconitine & Mesaconitine & Jesaconitine \\
\hline Frog & Lymph nodes & $0.7 \sim 1.1$ & $0.6 \sim 0.9$ & $0.5 \sim 0.7$ \\
\hline Mouse & $\begin{array}{l}\text { Subcutaneous inject. } \\
\text { Oral administ. }\end{array}$ & $\begin{array}{l}0.4 \sim 0.5 \\
2.0 \sim 3.0\end{array}$ & $\begin{array}{l}0.3 \sim 0.5 \\
2.0 \sim 3.0\end{array}$ & $\begin{array}{l}0.2 \sim 0.25 \\
1.0 \sim 2.00\end{array}$ \\
\hline $\begin{array}{l}\text { Guinea } \\
\text { Pig }\end{array}$ & Subcutaneous inject. & $0.04 \sim 0.06$ & $0.02 \sim 0.04$ & $0.02 \sim 0.03$ \\
\hline Rabbit & $\begin{array}{l}\text { Intravenous inject. } \\
\text { Subcutaneous inject. }\end{array}$ & $\begin{array}{l}0.05 \sim 0.07 \\
0.1 \sim 0.13\end{array}$ & $\begin{array}{l}0.04 \sim 0.06 \\
0.05 \sim 0.1\end{array}$ & $\begin{array}{l}0.03 \sim 0.05 \\
0.05 \sim 0.08\end{array}$ \\
\hline Cat & Subcutaneous inject. & $0.1 \sim 0.15$ & $0.08-0.1$ & $0.05 \sim 0.1$ \\
\hline Dog & $\begin{array}{l}\text { Subcutaneous inject. } \\
\text { Oral administ. }\end{array}$ & $\begin{array}{l}0.08 \sim 0.13 \\
3.0 \sim 10.0\end{array}$ & $\begin{array}{l}0.05 \sim 0.1 \\
3.0 \sim 5.0\end{array}$ & $\begin{array}{l}0.05 \sim 0.08 \\
3.0 \sim 5.0\end{array}$ \\
\hline Monkey & Oral administ. & $1.5 \sim 2.0$ & $1.0 \sim 2.0$ & $1.0 \sim 2.0$ \\
\hline
\end{tabular}

なお、トリカブト屬植物の Alkaloids が、いかに猛毒性を有するかを比較證明するため、 前出今井論文の第 7 表により Mouse に對する各藥物の致死量 (Table. 2) を揭出してお $<。$

Table. 2. Lethal dosage of poisons for Mouse (LD.50)

(after J. IMAI, 1949)

\begin{tabular}{|l|c||l|c|}
\hline \multicolumn{1}{|c|}{ Poisons } & $\mathrm{mg} / 10 \mathrm{~g}$ & \multicolumn{1}{c|}{ Poisons } & $\mathrm{mg} / 10 \mathrm{~g}$ \\
\hline Pirocarpine $\cdot \mathrm{HCl}$ & 0.625 & Strychinine $\cdot \mathrm{HNO}_{4}$ & 0.02 \\
Atropinae $\cdot \mathrm{H}_{2} \mathrm{SO}_{4}$ & 8.0 & Apo-morphine $\cdot \mathrm{HC}_{3}$ & 0.8 \\
Di-acetyl morphine $\cdot \mathrm{HCl}$ & 10.0 & Aconitine & $0.004-0.006$ \\
Morphine $\cdot \mathrm{HCl}$ & 4.211 & Mesaconitine & $0.003-0.005$ \\
Eserine salicylate & 0.006 & Jesaconitine & $0.002-0.003$ \\
Emetine $\cdot \mathrm{HCl}$ & 2.5 & & \\
\hline
\end{tabular}


このように考察を進めてくると、オクトリカブトには Aconitine 及び Jesaconitine が含有される故、矢毒として使用され可能性が充分有り得ることになる。

\section{IV. 賔 驗 の 部}

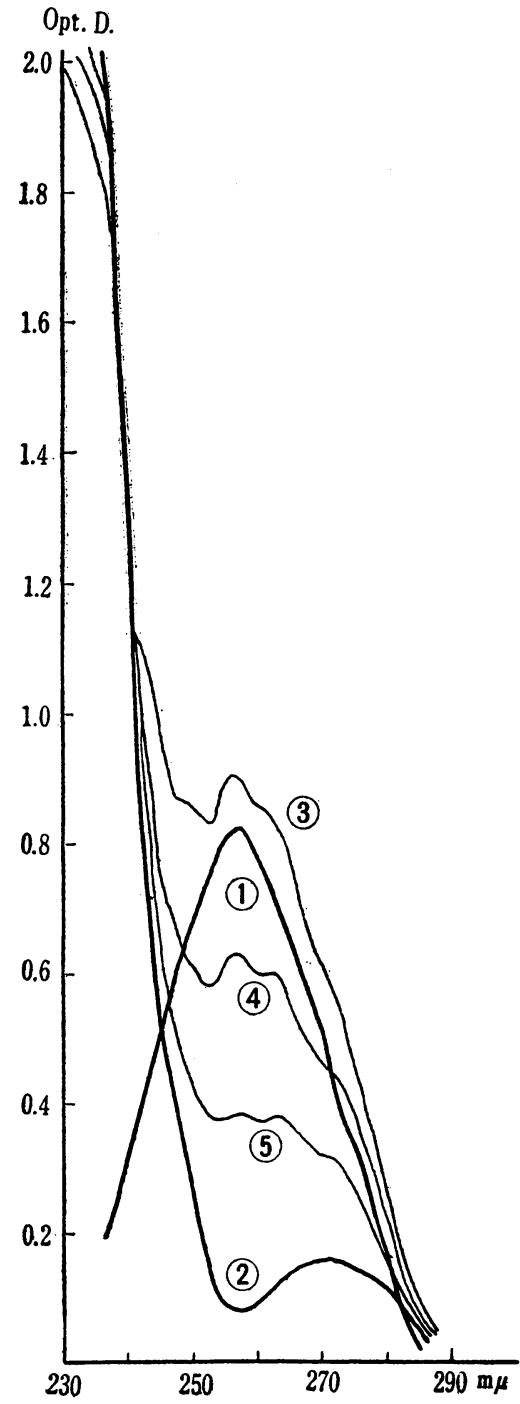

Fig. 7. Spectra of jesaconitine, mesaconitine and the mixture of the alkaloids in alcohol solution.

(1) Jesaconitine, $0.2 \mathrm{mg}$. in alc. $100 \mathrm{cc}$.

(2) Mesaconitine, $1.0 \mathrm{mg}$.

(3) Jesaconitine : Mesaconitine (1:3) $1.0 \mathrm{mg}$. in alc. $10 \mathrm{cc}$ (4) ": " (1:5) $1.0 \mathrm{mg}$. in alc. $10 \mathrm{cc}$. (5) " : " $(1: 10)$

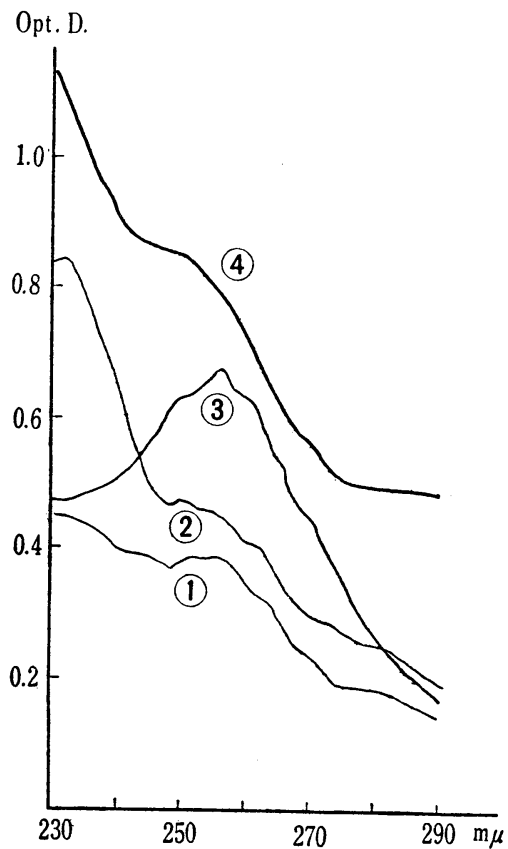

Fig. 8. Spectra of the free acids obtained from aconite root and the sample from F-407 in alchol solution.

(1) Alc. $(4 \mathrm{cc}$.) solution of the total free acids obtained from Katsuyamabushi (90 mg.)

(2) " Tashiroyamabushi (90 mg.)

(3) " Yezotorikabuto (90 mg.)

(4) " Alc. (4 cc.) solution of the total free acids obtained from the sample (260 mg.) (F-407)

\section{（1）トリカブト根 Alkaloid の微量取扱法}

\section{1. 呈色及び沈測反應}

トリカブト根 Alkaloid の確認反應として、 特異な反應は知られていないが、一般 Al一 kaloid の反應は示す。バナヂン酸・濃硫酸、 及びモリブデン酸・濃硫酸によりいずれも、暗 赤褐色の呈色を示す。又ヨードカリ蒼鉛により 橙赤色の沈澱を生ずる。前者は微量の場合は明 瞭でないが、後者は毛細管中の反應を試みれば 
數 $\boldsymbol{\gamma}$ の試料にもよく檢出し得る。

2. 吸收スペクトル

トリカブト根 Alkaloid の母核の吸收は $220 \mathrm{~m} \mu$ 以上には大體現われない。すなわち。 Aconitine 等安息香酸エステルとなつているものは、㚣息香酸の吸收に一致し、Jesaconitine の如くアニス酸のエステルとなつているものはアニス酸のそれに一致する (Fig. 7)。

トリカブト根中に含有される遊離酸として各種のものが知られているが、紫外部吸收を示 すものは、安息香酸、アニス酸等である。しかもこれらは、含有 Alkaloid の種類と平行し ている (Fig. 8 及ぴ Fig. 11 を比較)。

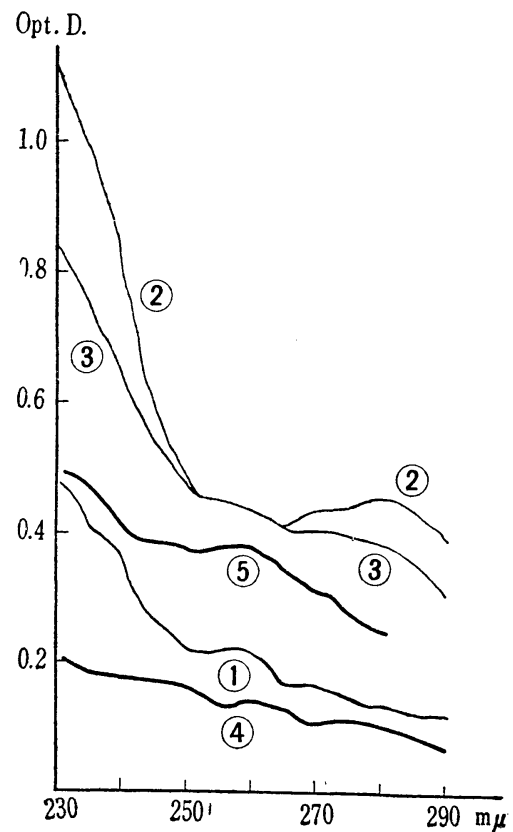

Fig. 9. Spectra of the extracts from aconite roots and poisoned material of the sample F-263 and F-259 in alcohol solution.

(1) Alc. (4 cc) extract of Katsuyamabushi (4 mg.)

(2) Alc. (4 cc.) extract of Tashiroyamabushi (4 mg.)

(3) Alc. ( $4 \mathrm{cc}$.) extract of Yezotorikabuto ( $4 \mathrm{mg}$.)

(4) Alc. $(4 \mathrm{cc}$.) extract of the sample (1.5mg.), obtained from F-263.

(5) Alc. ( $4 \mathrm{cc}$.) extract of the sample (3mg.), obtained from F-259.
Opt. D.

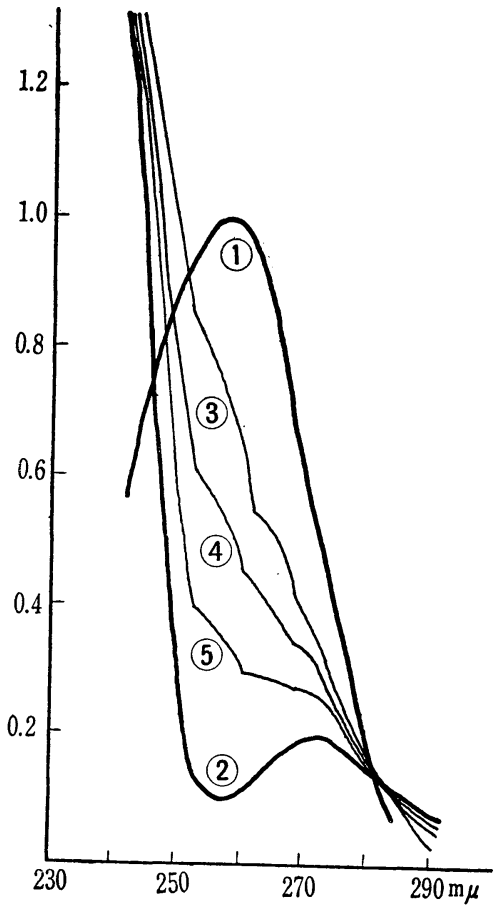

Fig. 10. Spectra of anisic acid, benzoic acid and the mixture of the acids in alcohol solution.

(1) Anisic acid $0.1 \mathrm{mg}$. in alc. $10 \mathrm{cc}$.

(2) Benzoic acid $0.3 \mathrm{mg}$.

(3) Anisic acid: benzoic acid (1:3) $0.3 \mathrm{mg}$. in alc. $10 \mathrm{cc}$.

(4) ": : " (1:5) $0.3 \mathrm{mg}$. in alc. $10 \mathrm{cc}$. (5) " : " $(1: 10)$

トリカブト根の抽出液そのものも、Alkaloid 及び遊離酸との關連性を示す (Fig. 9 を Fig. 8, 11 と比較) 兩種 Alkaloid が含有されている場合、その Alkaloid 及び遊離酸の 吸收は Fig. 7 及び Fig. 10 に示した合成吸收の如きものであろう。トリカブト根の成分 としては、Alkaloids 及び 酸の他に糖があるが、糖は大體紫外部の吸收はない。酸として 
は、安息香酸、アニス酸の外ベラトラム酸、アントラニイル酸が考えられるが日本產トリカ ブトでは、前二者に限定してもよいと考える。

3. 動物實驗による中毒反應

Aconitine, Mesaconitine, 及び Jesaconitine 等の毒性 (Table 1. 參照) はLD. 50 約 $0.1 \sim 0.2 \mathrm{mg} / \mathrm{kg}$ とされている。しかしこれらが加水分解されて、Acetyl 基を失つた Benzoylaconine では數百分の一、更に Benzol 基が加水分解された Aconine では 1/1,000 以下といわれる。實際矢毒として、抽出された粗 Alkaloid については、狀況が大 いに異なり、これが各種の Alkaloid の混合物であること、文リカブト根の保存方法及び 保存年月等による加水分解程度の差、さらに、Alkaloid の抽出方法等により、その毒性に

Opt. D.

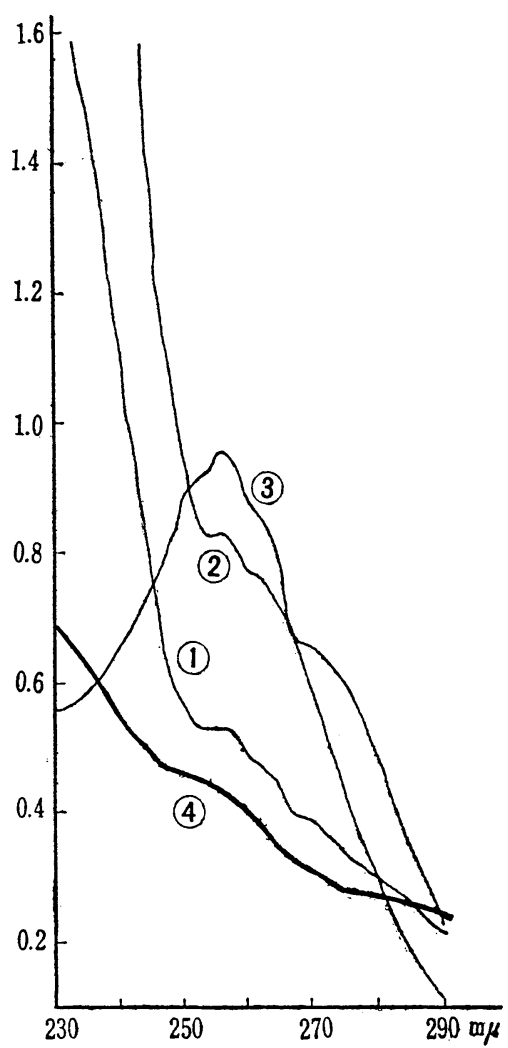

Fig. 11. Spectra of the alkaloids obtained from aconite roots and the sample $(\mathrm{F}-407)$.

(1) Alc. $(4 \mathrm{cc}$.) solution of total alkaloids obtained from Katsuyamabushi (90 mg.)

(2) " Tashiroyamabushi (90 mg.)

(3) " Yezotorikabuto (90 mg.)

(4) Alc. $(4 \mathrm{cc}$.) solution of the total alkaloids obtained from the sample (260 mg.) (F-407).
著しい差を生ずることは注意すべきである。

（2）矢毒成分の檢討

1.メタノール抽出物の吸收スペクトル

試料 F-259 より $3 \mathrm{mg}, \mathrm{F}-263$ より $1.5 \mathrm{mg}$ 。 の矢毒と推定される黑褐色物質を得、これをメ タノール $10 \mathrm{cc}$ にて 4 日間冷浸、メ夕ノール留 去して殘渣を Alc. $4 \mathrm{cc}$ に溶解して、紫外部吸 收を見る。對照として、勝山ブシ) (Aconitine 系)、田代山ブン (Aconitine 系)、エゾトリカ ブト (Jesaconitine 系) の根部乾燥粉末を同 樣に處理したものの吸收を示す (Fig. 9)。試料 はいずれも微弱ながら 250 260 $\mathrm{m} \mu$ 及び 270 $\mathrm{m} \mu$ 附近に吸收を示す。この吸收位置は、アニ ス酸及び安息香酸或は、そのエスデルに起因す る吸收と考えることは Fig. 7 及び Fig. 10 と 比較して可能である。

\section{Alkaloid の分離確認}

試料 F-407 より矢毒（竹晚も少量含有） 260 $\mathrm{mg}$ を得。これにメタノール $15 \mathrm{cc}$ を加えて、 4 日間室溫にて冷浸す。濾過メタノールを留去 して、黃褐色樹脂樣物質 $11 \mathrm{mg}$ を得。對照と して勝山ブン、田代山ブン及びエゾトリカブト 根乾燥粉末 $100 \mathrm{mg}$ より同樣處理して、それぞ れ $13 \mathrm{mg}, 28 \mathrm{mg}, 39 \mathrm{mg}$ の抽出物を得た。矢 毒抽出物 $11 \mathrm{mg}$ を $1 \%$ 監酸 $5 \mathrm{cc}$ に溶解、不 溶物濾過、濾液をアンモニア水でアルカリ性と し、クロロホルム抽出、クロロホルムを留去し て、微量の微黃色樹脂樣物を得。これを Alc. $4 \mathrm{cc}$ に溶解して、紫外部吸收を見る(Fig. 11)。 
このものも 250 260 $\mathrm{m} \mu$ 及び $270 \mathrm{~m} \mu$ 附近に吸收を示す。對照として前記勝山ブン、田代 山ブン、エゾトリカブトより得たメタノール抽出物の內 $10 \%$ を除去（抽出物の吸收測定に 使用）殘り $90 \%$ (すなわち、原試料 $90 \mathrm{mg}$ に相當）を全く同樣にして處理 Alkaloid を 得。その吸收を比較のため Fig. 11 に示す。矢毒はむしろ安息香酸エステル系の Alkaloid を含有している可能性がある。エゾトリカブトょりの Alkaloid は明かに Jesaconitine の吸收に一致して、大牛 Jesaconitine なることを示している。

吸收測定後アルコールを留去して、試料を回收、これを $1 \%$ 鹽酸 $0.5 \mathrm{cc}$ に溶解、毛細 管中にて、ヨード蒼鉛による沈澱反應を見るに、橙赤色沈澱を生じ、對照と全く同樣の反應 を呈し、Alkaloid なることが確認出來た。

3. 遊離酸の檢討

先の Alkaloid 抽出の際のアルカリ性母液を鹽酸々性として、クロロホルム抽出、クロロ ホルム留去して、安息香酸臭のある酸微量を得。これを Alc. $4 \mathrm{cc}$ に溶解して、スペクト ルを檢討す (Fig. 8), やはり 250〜260 m $\mu$ 及び $270 \mathrm{~m} \mu$ 附近の吸收を示す。對照の勝山ブ ン、田代山ブンに近い吸收を示している。

4. 遊離酸のペーパークロマトグラフによる檢討。

吸收測定後の試料を回收し、これを酸ヒドラチッドとしてペーパークロマトグラフにより 檢討するに下記の值を示した。

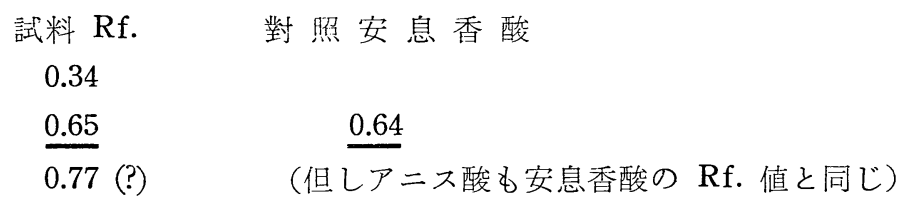

これにより明かに、安息香酸、或いはアニス酸に相當する酸を含有している。スペクトル の結果よりおそらく安息香酸及びアニス酸の混合物であろう。な㧧 Rf. 0.34, Rf. 0.77 (?) の酸については追求しなかつた。

以上を綜合して結論すれば、矢毒成分として Alkaloid が確認され、しかもこれは安息香 酸又はアニス酸エステル系 Alkaloid 或はこれらの混合物であろう。さらに粗抽出物、Alkaloid 及び酸共にトリカブト根のそれらに類似して紫外部吸收スペクトルを示すことから、 大體トリカブト根を使用した矢毒であるといつても大過なからう。

さらに又、動物實驗によりこの抽出鹽基が Aconite Alkaloids の中毒症狀の特徵を示 し、且つ猛䓯性を發揮するならば、確定的と言い得るが、殘念ながら動物寶驗に於ては、試 料が微量のため顯著な徵候を認められず、所期の目的を達成し得なかつた。

括わりに、本研究をなすに當り、終始懇篤なる御指導を頂いた東京大學醫學部藥學科岡本 助敉授に對し、又同大學理學部植物學敉室、同人類學敎室及び早稻田大學考古學趼究室の各 位の御援助に對し、深甚なる謝意を表する。

な扮研究費の一部は昭和 29 年度文部省科學研究助成補助金によるものである。記して、 感謝の意を表する。 
註

(1)衫まがりだけ。Sasa paniculata Makino et Shibata. アイヌ語： rumne-top (rúm-ne-top)、は rum rup と同じく、「頭」の義。日本語の矢瓦がア イヌでは反對に áy-rum (矢頭) なのである。(知里：アイヌ語亂典)

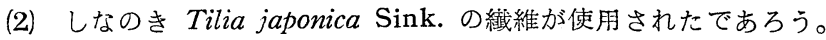

(3) あし。よし。Phragmites communis Trin.アイヌ語： supki は (súp-ki) 矫にする稈という意。

(4) ほおのき Magnolia obovata Thunb. で作る。アイヌ語： pus-ni, 或は ikayop-ni はいずれも "矢筒の木" の意。

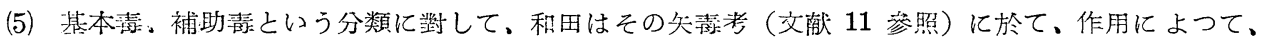

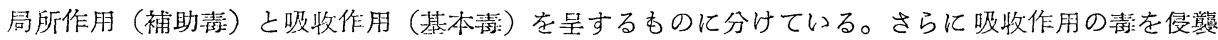

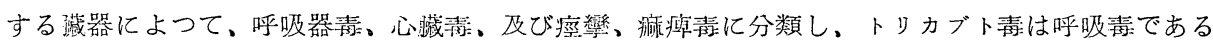
と同時に猛烈な心藏毒:であると記している。(p. 62)

(6) インド産 Aconitum heterophyllum Wall から抽出された Alkaloid で分子式は $\mathrm{C}_{22} \mathrm{H}_{31} \mathrm{O}_{22} \mathrm{~N}\left(\mathrm{C}_{22}\right.$ $\mathrm{H}_{33} \mathrm{O}_{2} \mathrm{~N}$ ) で。低䡒性の代表的のものである。

（7）毒性の低下は溶液內で、これらの Alkaloid が加水分解するととに起因すると思われる。

(8) 勝山ブシ。Aconitum sanyoense Nakai, var. typicum Nakai.（含有成分については。落合・閉本 (1952) 藥誌: Vol. 72, No.6. pp. 816〜825 參照)

（9）田代印ブシ。Aconitun tasircmontanum Nakai, には Mesaconitin $\left(\mathrm{C}_{33} \mathrm{H}_{45} \mathrm{O}_{11} \mathrm{~N}\right)$ を多く念有す る。（落合・閂本 (1952) 藥誌：Vol. 72. No. 12, pp. 1605 1607 參照)

(10) エゾトリカプト。Aconitum yesoense Nakai には Jesaconitine $\left(\mathrm{C}_{30} \mathrm{H}_{40} \mathrm{O}_{12} \mathrm{~N}\right)$ を含有する（文献 13 參照)

\section{文献}

(1) 知里奥志 保：1953. 分類アイヌ語蝣典、第 1 卷、植物篇。 p. .45

（2）占野清人：1942. (1948) 原始交化の探求。pp. 153 192.

(3) 三上次男: 1943. 民族學研劣。新 Vol.1, No.3, pp. 255〜289.

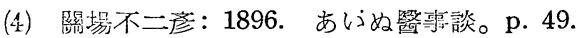

(5) LEwin, L. : 1923. Die Pfeilgifte, s. 47.

(6) Hutron, J. H. : 1938. The Geographical Journal, Vol. XCI, No.3, p. 217.

（7）松浦武四郎：1863. 身蝦夷日誌 初篇。(日本占典全集本。pp. 12１3）

(8) 知里奥志保: 1953. 前揭言。 p. 145.

(9) 宮部金㧞: 1949. 植呼。Vol. XXIV, No.1 12, pp. $2 \sim 7$.

(10) 關場不二疹: 1896. 前掍意。pp. 37〜38.

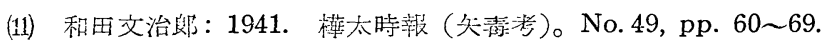

(12) NAKAI, T. : 1917. Tokyo Bot. Mag. Vol. XXXI, No. 368, pp. 219 231.

(13) $\quad$ : 1908 . ibid. Vol. XXII, No. 260, p. 136

(14) - : 1914. ibid. Vol. XXVIII, No. 327, pp. 59 60.

(15) TAkedA, H. : 1915. Notes, R. B. G., Edin., Vol. VIII, No. 39, pp. 232 233.

(16) NAKAI, T. : 1917. Tokyo Bot. Mag. Vol. XXXI, No. 361, pp. 25〜26

(17) — : 1917. ibid. pp. 26〜27.

(18) 杉野目晴貞：1943. トリカブト屬アルカロイドの研究概要。p. 6.

(19) Geiger, Hesse : 1833. Ann., 7, 269.

(20) Majima, Suginome : 1925. Ber., 58,2048. Morio, S. : 1929. Ann., 476, 181.

(21) Suginome, Imato : 1950. J. Fac. Sci., Hokkaido Univ., Ser. III, Chem., 4, 33.

(22) — : 1950 . ibid.

(23) OChIAI, OKAмото : 1952 1956. (Reports Nos. 1 17). Yakugaku Zasshi and Pharm. Bull. 
(2A) HENRY, T. A. : 1949. The Plant Alkaloids, p. 673.

(25) 杉野目晴貞: 1943. 前揭玨 p. 5, Table. 2.

(26) Majima, Morio : 1924. Ber., 57, 1472. 1929. Ann., 476, 171, 194, 203.

1932. Ber., 65, 599 .

(27) 黑田朝太郎：1951. 日本藥理學雜誌。Vol. XLVII, No. 1, p. 22. (第 1 表)

(28) 今井治郎: 1949. 㷊京學科大學雜誌。Vol. 7, No. 1, p. 161.

(29) — : 1949 . 前揭琵 p. 164 (第 7 表)

\section{On the Aconite Arrow Poison of the Ainu}

\section{Microchemical Studies}

\section{MOTOSUKE ISHIKAWA}

It has been said that the arrow poison (ayyop in Ainu language) used by Ainus in Hokkaido (Yeso) is prepared from the root of Aconite. However, no studies have been made on the chemical components of the arrow poison itself, especially from the point of Ethno-Botany.

The author obtained some samples from a dozen or so of poison arrows stored in Anthropological Institute, Faculty of Science, University of Tokyo, and submitted the substances assumed to be arrow poison to chemical analysis. These samples were obtained from three poisoned arrow heads, two attached to two poisoned arrows (Sample Nos. F-259 and F-263), one from an arrow case (Sample No. F-407. Called pus-ni in Ainu language and probably collected in the Iburi area). The dark brown substance, assumed to be arrow poison, was obtained in an amount of 3, 1.5, and $260 \mathrm{mg}$. respectively, from which poisonous principles were extracted and were identified as alkaloid by color and precipitation reactions.

Further examination of their ultraviolet absorption spectra indicated that the alkaloid extracted from the arrow poison was a mixture of alkaloids of benzoic or anisic acid esters. Since alkaloids of this type are characteristic of aconite alkaloids, there seems to be a great possibility that the alkaloid extracted from the arrow poison originated in aconite.

Animal experiments on toxicity could not be made due to the small amount of the samples available. 